\title{
Illegal Settlement Growth Pattern with its Eco Settlement and Environmental Sanitation in the Coastal Area of Manado City
}

\author{
Nixon J. Sindua ${ }^{1}$, Marjono ${ }^{2}$, Gatot Ciptadi $^{3}$, Hagus Tarno ${ }^{4}$ \\ \{sinduajnixon1960@gmail.com ${ }^{1}$ \} \\ Universitas Negeri Manado, Indonesia ${ }^{1}$ \\ Universitas Brawijaya, Indonesia ${ }^{2,3,4}$
}

\begin{abstract}
Illegal settlements growth in urban areas often causes complex problems. Especially related to unclear land ownership status. These characteristics are found in the coastal areas of Manado City and its Eco settlement and environmental sanitation that are not in accordance with the expected standards. This study aims to analyze the characteristics of the illegal settlement's growth pattern accompanied its Eco settlement and environmental sanitation. The method used in this study is spatial method by taking into account the dominant factors in relation with the characteristics of illegal settlements growth, its eco settlement and environmental sanitation. Based on the results of on the characteristics of illegal settlements growth pattern, its eco settlement and environmental sanitation, where the illegal settlements growth pattern on the coastal area of Sindulang I ward is faster than Maasing ward because the Sindulang I ward with its trade center is very close supported by better accessibility. For its eco settlement and sanitation, the environment still needs better arrangement in Sindulang I and Maasing. So with this matter it is necessary to produce settlement arrangement model on the coastal area which is friendly to its environment.
\end{abstract}

Keywords: Illegal Settlements Growth, Eco Settlement, Environmental Sanitation.

\section{Introduction}

Illegal settlements growth pattern in urban areas often causes complex problems. Especially related to unclear land ownership status. Usually the population in urban areas is very diverse, both from the work types and education and socio-cultural conditions. Residential places in urban areas also vary in shape. Ranging from buildings that are luxurious palaces to huts that are unfit for human habitation, in urban areas as well as its environmental sanitation.

Cities as form of space and as ecosystem that has multiple functions in serving the needs of its inhabitants. The demographic growth of urban population both from birth and migration from villages and from other cities is very unique problem. Especially regarding settlements, usually in the city, there are what is called slums and illegal settlements.

The Manado City is one of the cities in Indonesia which is located in coastal area with all the activities of the population and its settlements, accompanied by very rapid growth of development because the growth trend causes population pressure with its socio-economic dynamics. The growth and development of Manado City tends towards the coastal area or the 
sea, including the settlement system. So causing many community activities tend to the coast, both to enjoy the beach beauty and used by informal sector for livelihood. In line with the development of Manado City, the settlements growth also follows.

The coastal area of Manado city is considered worthy of being used as case study, where the feasibility level of its settlements needs special attention. The condition of illegal settlements growth pattern, both in its eco settlement and environmental sanitation needs special attention. Especially on the characteristics of both illegal settlement's growth patterns as well as its eco settlement and environmental sanitation.

\section{Research Method}

a) The research method that will be used in this study uses spatial method. In this case, to examine the characteristics of illegal settlements growth pattern, it is associated with its eco settlement and environmental sanitation in the coastal area of the Manado City.

b) Concepts and Variables

The concept of illegal settlements pattern in the Manado City can be described in 3 research variables, namely: the illegal settlements growth pattern, eco settlement, environmental sanitation.

c) Operational Variables Definition

Illegal settlements growth pattern is form of increase in the occupation area that is illegally occupied, without legal force in this case the certificates ownership relating to the land and building permit in relation to the buildings.

Eco settlement is settlement system that has strata or degree (feasibility) that deserves attention for its handling.

Environmental sanitation is environment that has healthy standards including the physical building and land.

d) Population and Sample

The population in this study is the coastal area of the Manado City.

The sample uses purposive sampling taken as representatives of 2 wards namely: Sindulang I and Maasing wards.

e) Data collection technique

In collecting data in this study using:

- Collection of documents (maps in 2000, 2005, 2010 and 2014)

- Interview

- Questionnaire

f) Data analysis technique

To find out the study results, using the R scale formula and Chi square

g) Research sites

This research was conducted in the coastal area of the Manado City.

h) Research Time

Research on the illegal settlement's growth patterns with its eco settlement and environmental sanitation in the coastal area of the Manado City was carried out for 6 months.

i) Research Instruments

The instruments used in this study are: Manado City map, questionnaires, cameras, and notebooks. 


\section{Results and Discussion}

The process of illegal settlements growth pattern is essentially oriented to increasing the buildings (houses) number and area (land) expansion used for settlements. The increase occurred due to various certain factors. Especially beginning from the migrants who come from villages to cities with the intention of finding work in the city. Due to the limited skills of migrants with very minimal educational strata, employment opportunities, especially in the formal sector, are very small. Then in the informal sector there is big chance, but the problem lies in the lack of professional development. Because of lack of knowledge and skills. Thus, arises powerlessness in the economic field, thus making these migrants occupy inadequate residential areas including land and building houses. Drakakis - Smith (1980) pointed out that in the process of illegal settlements often occur processes of "invasion" and "infiltration". This process usually takes place continuously, if the area does not provide better life expectancy. Then in this section will be discussed regarding the growth patterns process of illegal settlements with its eco settlement and environmental sanitation in the coastal area of the Manado City.

Factors influencing include: spatial and time perspective, especially on factors that affect the illegal settlements growth pattern with its eco settlement and environmental sanitation in Sindulang I and Maasing urban areas in Manado.

\subsection{Spatial and Time Perspective}

The perspective referred to here is description of spatial and time characteristics in relation to the process of illegal settlements growth patterns. he spatial perspective study in this case shows the place where it occurred, namely in Sindulang I and Maasing. Then study the perspective of timing orientation of the time period the process of illegal settlements growth pattern. The period in question is the period 2000, 2005, 2010 and 2014.

Based on the description of the process of illegal settlements growth patterns in Sindulang I ward in the period 2000-2005 the land is 1 hectare and the number of houses 120 units, in 2005-2010 the land became 2.5 hectares with the number of houses 180 units, in 2010-2014 the land was 3 hectare with the number of houses 300 units.

For the Maasing ward in the period of 2000-1005 the land was 0.5 hectares and the number of houses was 80 units, in 2005-2010 the land became 1 hectare with total of houses 100 units, while in 2010-2014 the land became 1.5 hectares with the number of houses 220 units.

The two wards mentioned above have different growth as in the case of Sindulang I, the growth is greater than Maasing. Because in Sindulang I it is closer to the city center.

Likewise, eco settlement and environmental sanitation in Sindulang I is very inadequate compared to the village of Maasing.

\subsection{Operational definition}

a) The decline in illegal settlements is a process of change from small to large the area, as well as guarding the building units related to the illegal occupation of land or settlements occupied illegally, without legal force and without the necessary permits as a basis for protection of the land (Drakakis Smith, 1980).

b) Distribution pattern of settlement is a form of distribution of settlement in the process of growth, which forms circular or elongated by following three patterns of distribution 
including: clustering patterns, unevenly distributed patterns and evenly spread patterns (P.J Clark \& F.C Evans in Nursid Sumaatmadja, 1988).

c. Settlement density is the level of the number of building units in a particular region or region. To calculate this density level, that is: the number of building units divided by area.

d. Land and building status is the existence of land and buildings occupied by settlers, in relation to the presence or absence of ownership documents (certificates and IMB) of the land and buildings occupied.

e. Accessibility is the level of ease of a place to be reached (both with time, cost or physical) from other places in a system (Janelle D. G, 1974). According to Pacione (1984), accessibility can be divided into two namely physical accessibility or locational accessibility of social accessibility or personal accessibility. Locational accessibility is closely related to elements of distance, infrastructure and means of transportation; while personal accessibility relates to the ability or potential of individuals to achieve service. The potential concerns social and economic potential such as family structure income and individual education level.

f. Distance is the boundary between two locations using units of meters or kilometers. Then with the figures obtained from the results of this measurement, can determine the classification of distance (far, medium and near) by calculating the index of its category.

g. Time is the whole series of times that have been or will be passed or the length of a certain time, especially in relation to the age of settlements (land, buildings) occupied by settlers in one area.

h. Law is a process of enacting laws or regulations from the central and regional governments in a certain region, especially in relation to the control of settlement areas.

i. The driving and pulling factor is the perception of a person to come to a certain place (city), and stay permanently in that area (Teluk Manado and Kali Tondano).

j. Income is the amount of income that is realized with the real value of money, where the money is expressed in units of rupiah per month. The income referred to is the income of the husband or wife as well as other family members who are already earning income, whether obtained from primary or side jobs.

k. Education is the highest level of formal education achieved by the head of the family based on the length of success in attending education in units of the year.

1. Livelihoods are an effort of settlers engaged in the formal and informal sectors, which show different characteristics from one another.

\subsection{Characteristics of Respondents}

Most respondents were aged between 15-64 years. Specifically for the Manado Bay area (Kelurahan Sindulang I) by 100 percent, while Kelurahan Maasing by 95 percent. This shows the productive age group, because starting in 1970 there was a massive migration with the intention of looking for work in the city, especially the city of Manado.

The sex of the respondents was mostly male compared to female. Especially for the Manado Bay area (Sindulang I Village) by 91.7 percent, while in Maasing Village by 90 percent. This is because men are considered to be the head of the household, unless they are already widowed.

The highest number of respondent family members is 6 people, 38.3 percent for the Manado Bay area (Sindulang I Village), while in Maasing Village, the most number is 5 
people for 35 percent. Thus, it turns out that the two regions mostly do not follow the KB program.

The highest number of respondent ethnic groups is the Sanger Tribe at 75 percent for the Manado Bay area (Sindulang I Village), while in the Maasing Village the most Gorontalo tribe is 65 percent. This is due to the worker's origin as a fisherman for Manado Bay, and as a street vendor.

The education level of most respondents was elementary school at 68.3 percent for the Manado Bay area (Sindulang I Kelurahan), while Maasing Kelurahan was 42.5 percent. With the level of elementary school education, also contributed to the low comprehension of information, knowledge and attitudes of respondents.

Type of respondent's livelihood is his main occupation as the main source of income. Most of the livelihoods are 33.3 percent of street vendors in the Manado Bay area (Maasing Kelurahan) by 75 percent. This shows that in both regions the respondents worked more in the informal sector compared to the formal sector.

The level of income of the respondent's household is the level of income of all family members who are used together to support the family's needs which are calculated monthly or annually. It turned out that most of the respondents' household income level in the Manado Bay area (Sindulang I Kelurahan), with a low household income level of 75 percent, while in Maasing elurahan) with a moderate household income level of 62.5 percent. This is due to the uncertain livelihoods especially in the Manado Bay area.

The length of stay of respondents is mostly over 17 years, especially in the Manado Bay area (Kelurahan Titi $\neg$ wungen) by 48.3 percent; whereas in Kelurahan Maasing by 40 percent. This is due to the suitability with the surrounding environment including security and peace as well as other factors, so that respondents are happy and comfortable staying at the two regions.

\subsection{Settlement Characteristics}

The way to obtain respondent's land is mostly by grabbing. Specifically for the Manado Bay area (Kelurahan Sindulang I) at 83.4 percent, while for the Maasing Village by 75 percent. This is due to the fact that the two regions are state lands that are considered to be noman's land, so the tendency to use this method is greater than the other methods.

The majority of respondents hold land certificates do not have certificates. Specifically in the area of Manado Bay (Kelurahan Sindulang I) at 88.3 percent, while for Kelurahan Maasing at 87.5 percent. This indicates that most of the respondents' land in the two regions is still wild.

The way to obtain respondent building is mostly by building it yourself. Specifically for the Manado Bay area (Sindulang I Kelurahan) by 76.7 percent, while Maasing Kelurahan was 82.5 percent. This is due to the ease of obtaining buildings from used and other materials at low prices.

Most of the IMB ownership of respondent's houses do not have 1MB. Specifically for the Manado Bay area (Kelurahan Sindulang I) by 96.7 percent, while Maasing Kelurahan was 92.5 percent. It turned out that the houses occupied by respondents in these two areas were mostly still wild.

\subsection{Characteristics of Residential Houses and Respondents' Environments}

In general, the physical quality of the respondents' houses was mostly of poor quality. Specifically, in the area of Manado Bay (Kelurahan Sindulang I) by 58.3 percent, while those in Maasing Village by 75 percent. This is because most respondents build houses with low 
quality building materials at low prices. Especially in relation to the limited cost of buying building materials.

The quality of respondent's housing facilities is mostly in the Manado Bay area (Sindulang I Kelurahan) with 40 percent poor quality, while in Tondano River (Maasing Kelurahan) with a moderate quality of 50 percent. This means that generally the quality of housing facilities in Maasing Village is better than in Manado Bay.

The quality of the respondent's home environment is mostly of poor quality. Specifically in Manado Bay (Kelurahan Sindulang I) by 58.3 percent, while Kelurahan Maasing was 50 percent. It turns out that the quality of the respondent's home environment in both regions is categorized as slum.

\section{Conclusion}

Illegal settlements pattern of growth in Sindulang I and Maasing, shows differences. Where in Sindulang I ward the growth is faster because the area is close to the city center compared to the Maasing ward which is distant from the city center.

The eco settlement condition and environmental sanitation in Sindulang I ward is very inadequate compared to those in Maasing ward.

\section{References}

[1] Agung Wicaksono, 2011. Resettlement Program of Brantas River Residents in Malang City, East Java (I-PAL.Vol.1 No. 2 Hal 72-139, February 2011).

[2] Bintarto, 1983. Rural-Urban Interaction and Its Problems. Jakarta: Ghalia Indonesia.

[3] Bintarto, 1984. Urbanization and its Problems. Jakarta: Ghalia Indonesia.

[4] Dahuri et al, 2001. Integrated Management of Coastal and Ocean Areas. PT. Pradia Paramita, Jakarta.

[5] Dwi Walojo et al. 2010. The Concept of Structuring the Ngemplakrejo Fishermen Settlement Area as Impact of the Development of Pasuruan City. Department of Architecture ITS, March 2010 (National Seminar on Housing and Settlements in Urban Development).

[6] Drakatis, Smith, 1980. Urbanitation, Housing and the Development Process. New York: ST Martinus Press.

[7] Hadi Sabari Yunus, 1987. Settlement Geography and Some Settlement Problems in Indonesia. Yogyakarta, Faculty of Biography, Gajah Mada University.

[8] Hadi Sabari Yunus, 198 9. Subject Matter and Biographical Research Methods for Urban Settlements. Yogyakarta, Faculty of Biography, Gajah Mada University.

[9] Hadi Sabari Yunus, 2010. Contemporary Regional Research Methodology. Publisher of East Celeban Student Library UH III / 548 / Yogyakarta.

[10] Hanni Poli et al., 2011. Spatial Planning Analysis of Coastal Areas Facing the Impact of Global Warming Case Study of the Coastal Coastal Manado City, Sabua Journal Vol. 3 N0. 3: 1-8, November 2011.

[11] Kodoatie et al. 2007. Integrated Beach Management. Andi Semarang Publisher.

[12] Marina Ayu Wulandari and Sunarti, 2013. Typology of Coastal Area Settlements on Climate Change in Tegal City. Journal of Engineering PWK 1 / Vol. 2 No. 1, pp. 85-93.

[13] Nugroho and Dahuri, 2004. Regional Development, Social and Environmental Economic Perspective. LP3ES Indonesia library: Jakarta.

[14] Nursid Sumaatmadja, 1988. Geography Study, An Approach and Financial Analysis. Bandung Alumni.

[15] Pamudji R, 1980. Urban Development in Indonesia. Jakrta: Ichtiar Baru-Van Hoeve. 
[16] Patrick MC Auslan, 1986. Urban Land and People's Protection Jakarta: PT. Graha Media. 